\title{
Strates
}

STRATES Matériaux pour la recherche en sciences sociales

2| 1987

Mélanges

\section{Division sociale de l'espace en Région Ile-de-France}

\section{(2) OpenEdition}

1 Journals

Édition électronique

URL : http://journals.openedition.org/strates/342

DOI : $10.4000 /$ strates.342

ISSN : $1777-5442$

Éditeur

Laboratoire Ladyss

Édition imprimée

Date de publication : 1 janvier 1987

ISSN : 0768-8067

Référence électronique

"Division sociale de l'espace en Région Ile-de-France », Strates [En ligne], 2 | 1987, mis en ligne le 08 décembre 2004, consulté le 08 septembre 2020. URL : http://journals.openedition.org/strates/342 ; DOI : https://doi.org/10.4000/strates.342

Ce document a été généré automatiquement le 8 septembre 2020

Tous droits réservés 
Division sociale de l'espace en Région Ile-de-France 